\title{
Fractal Geometry as a source of innovative formations in interior design
}

\author{
Omniah Bahaa Ibrahim
}

Teaching Assistant, at Faculty of Applied Arts, Interior Design \& Furniture Department, Helwan

University, Giza, Egypt

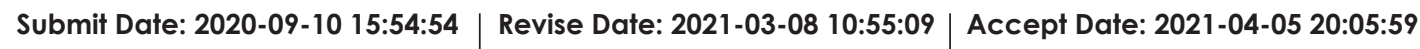

DOI: 10.21608 /jdsaa.2021.42275.1075

\section{Keywords:}

Fractal Geometry, innovative formations, Interior Design, furniture design.

\begin{abstract}
:
Fractal geometry was the best to describe natural shapes, as it can result to creating a very complex shapes but with a very simple laws and steps. Those shapes were not comprehended at first by scientists, but after using technology it became easy to understand and use in many aspects of our lives. Although fractal science is a mathematical branch but this branch of science nowadays acts as an inspirational tool in Interior design, furniture design and architectural design because of its aesthetic appeal and its ingenuity in describing natural objects. Ecosystems has an internal order that seems chaotic and fractal geometry was the door that opened new ways for understanding ecosystems. Across different historical design styles and across different cultures, each one of them was aiming to reach the grace in each aspect of the design; ecosystem has always been the source of inspiration to reach what they were aiming for.

Interior and furniture designer is the main responsible of enhancing the life of the space or furniture user, and finding out that most of our local interior and furniture designers are not fully aware of the importance of fractal geometry in design and the connection between it and the ecosystems, and how fractal geometry can help in analyzing and giving different taste to the historical and modern designs. The research paper aims through the study of fractal geometry and its characteristics, also the study of ecosystems as a source of inspiration and its characteristics aims to find the connection between them to help interior designers, furniture designers to create contemporary designs that copes with this modern era and get benefit of the technology and new sciences discovered. Finding the connection was done by an analytical study to compare the characteristics of each of the fractal shapes, ecosystems and how it can be found in interior, furniture and architectural design.
\end{abstract}




\section{1-Introduction:}

Fractals are surrounding us in nature and in many designs such as interiors, buildings, furniture and other objects. Because of its aesthetic appeal fractals are considered more than an abstract mathematical equation, they became essential in the design process of contemporary, elegant interior design and furniture design that acquires man's appreciation. Ecosystems has its own way of ordering things as a result of different factors affecting it, it shows order that is partially chaotic. Studying the characteristics of fractal shapes, characteristics of natural shapes and comparing them with interior, furniture and architectural design also sing up to date technologies and sciences in design will helps the designers in developing a well-designed contemporary interior and furniture design forms.

\section{2-The research problem}

1- Using ready-made molds from fractal formations in interior design and furniture without knowing its sources and engineering assets.

2- The spread of fractal geometry applications as a global language in interior design and furniture, with the lack of keeping pace with it locally.

\section{3-The research aim}

- To the affinity between ecosystems, fractal geometry and the interior design, furniture design to create contemporary designs that answers the cultural and artistic needs of this century. By knowing the common characteristics between them, and how each of them has this quality and to what extent it is inherited. Monitoring and analyzing the relationship between ecosystems and fractal geometry for access to interior design and furniture that meet contemporary cultural needs locally.

\section{4-The research assumes}

That fractal geometry, ecosystems and design has many common qualities, and getting to understand these qualities, and how it is found in each of them will help designers in having contemporary designs that have the good impact of nature on the wellbeing of the space user.

The fractal geometry is a cosmic geometry that represents its growth and continuation is considered a source of inspiration for designers for designs in in- terior design and furniture that are modern and contemporary.

\section{5- Research Methodology}

Description and analysis of the relationship between fractal geometry and environmental systems, with an analysis of applications of this relationship in interior design and furniture.

\section{6-Theoretical frame work}

\section{Fractal geometry}

Fractal geometry is the study of mathematical shapes that shows different levels of self-similarity at different scales, and has the glimpse of infinity. Understanding the principles of fractal geometry leads to more understating of natural structures and shapes which will help inspire designers with more shapes. Benoit Mandelbrot coined the term "Fractal" and described it as follows:

"A fractal is a rough or fragmented geometric shape that can be subdivided in parts, each of which is at least approximately a reduced/ size copy of the whole." [3]

\section{History of fractal geometry}

"Benoit Mandelbrot" had advantage of the work of predecessors' scientists who discovered shapes that did not follow the rules of Euclidian mathematics and had a glimpses into infinity [6: P4], such as George Cantor, Minkowski, Giuseppe Peano, Waclaw Sierpinski, Helge Von Koch, Heighway, Gaston Julia and others, in which their work was called "Mathematical Monsters" [7: P61].

Cantor Dust: created by dividing a line into 3 parts, then removing the middle part, then repeating the same process on the remaining two lines, by repeating the process to infinity several lines will be created till the line length become zer like a dust. (see Figure 1-a) [6: P4]

Minkowski curve: curve is created by dividing a straight line into 4 segments and replacing the middle 2 segments with the curve of 6 segments, and by repeating the same steps on each segment, the curve length will grow faster (see Figure 1-b) [4: P13]. Peano Curve: was created by Giuseppe Peano, by drawing a St. Line part of it is substituted by other lines and by repeating this process the lines fill the region leaving less space between lines. If this process is repeated till infinity theoretically it will fill the 
the space (see Figure 1-c) [6: P5].

Sierpinski gasket and carpet: the gasket can be started by drawing a solid triangle replaced by three smaller copies of the original triangle. By repeating the same steps on each of the three triangles, and by repeating the process endlessly, each small triangle will be copy of the whole triangle [6: P5]. Sierpinski has also created the carpet by applying the previous steps but on a square. (as shown in Figure 1-d,1-e).

Koch Curve and Snow flake: Curve was created by drawing a St. Line then dividing it into 3 parts, by replacing the middle part with 2 lines forming 2 sides of an equilateral triangle with no base, then by repeating the same steps on each of the remaining lines over and over, the result will be the Koch curve. In which each small part of the curve will be similar to the whole curve.

To create the Koch snowflake, is created by repeating the previous steps on the sides of equilateral triangle, the end shape will be Koch snowflake ( see Figure 1-f)

Heighway's Dragon: by John Heighway, that can be described this way: starting from a base segment, replace each segment by 2 segments with a right angle and with a rotation of $45^{\circ}$ alternatively to the right and to the left (1960) [6: P5] (see Figure 1-h) complex plane through the iterations of $\mathrm{x} 2+\mathrm{c}$ or $\mathrm{x} 3+\mathrm{c}$ (see Figure 1-i) [7: P121].

Mandelbrot Set: the scientist Benoit Mandelbrot discovered one of the most complex and beautiful objects ever created, which belonged to a category of fractals called escape time fractals, which was created by calculating each point on the complex plane and an imaginary plane by a large amount of iterations of the formula $\mathrm{xn}+1=\mathrm{x} 2+\mathrm{c}$ resulted in creating a self-similar shape with many details (see Figure 2), then these shapes became very popular for its aesthetic appeal [6: P7].

Benoit Mandelbrot is considered the father of modern Fractal Geometry, the term "Fractal" was first coined by "Benoit Mandelbrot" in his book "the fractal geometry of nature" in 1982, the word is derived from the Latin word "fractus" which implies broken something [3: P4]

3. Characteristics of fractal form:

According to Benoit B. Mandelbrot, fractal is considered that object or structure that consists of fragments with variable orientation and size but of similar appearance. This feature gives the fractal some special geometric properties the length and the relationship between surface area and the surrounding space, and many other features that are important for identify

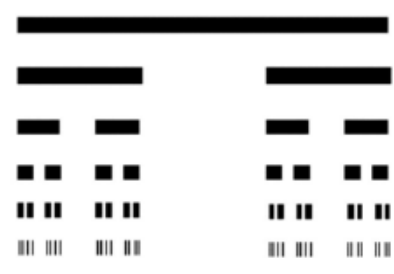

a-Cantor Dust

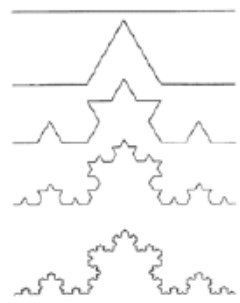

f-Koch Curve

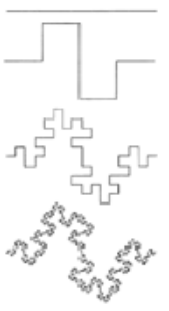

b- Minkowski curve
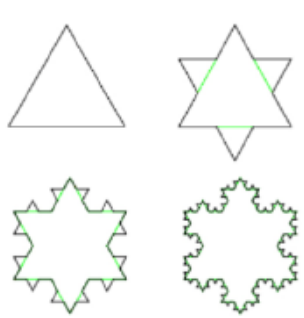

g-Koch Snowflake
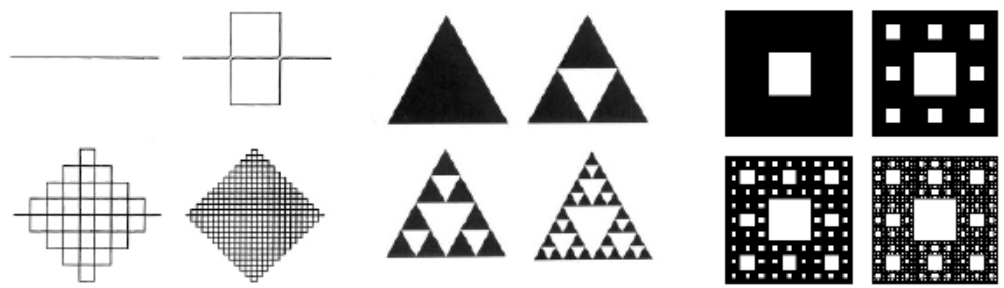

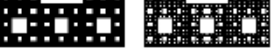
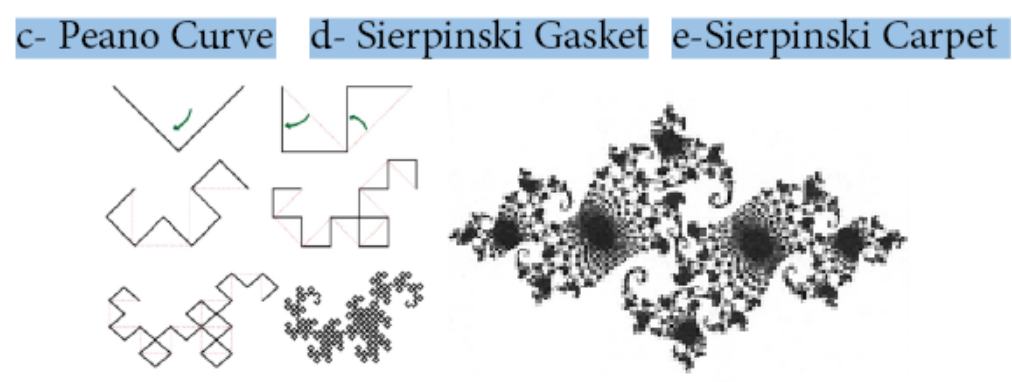

h- Heighway's Dragon

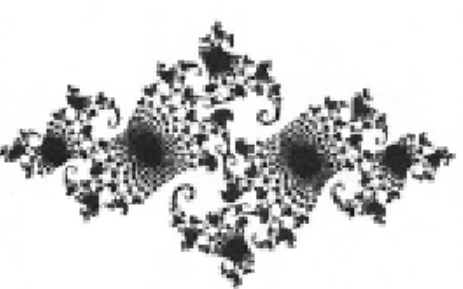

i- Julia curve
Figure 1: Fractal shapes [1] [2] [4]

Julia curve: It became famous after Benoit Mandelbrot had brought it back to light. Julia sets live in the inin identifying and understanding the fractal shapes and what makes it unique, such as:

Self-similarity: is the underlying theme in all fractals in different ways, if parts of a figure or object are 


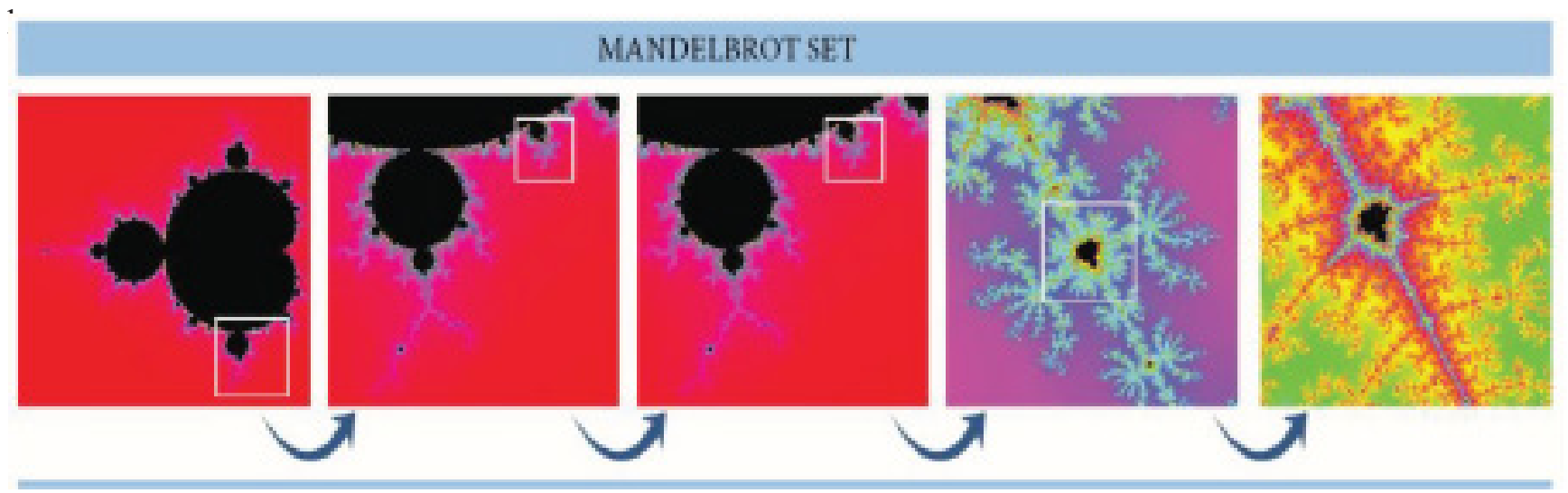

Figure 2: Zooming in Mabdelbrot Set [5]

small replicas of the whole then it is called self-similar [10: P21].

In mathematics self-similarity means transforming all dimensions of a shape by the same factor, so the new shape can be smaller, larger, rotated and/or translated, but it remains similar to the original one. There are two types of transformation that can be done on the shape, first the similarity transformation where all the object is reduced or enlarged by the same factor, Second the Self-affine transformation where the object is reduced unequally in one or more dimensions, or internal angels of the shape was changed [4: P14-15]. Roughness: Is one of the main Characteristic of a fractal form, we can find this quality evident in the Mandelbrot Set as the edges and details found in the set has a rough edge.

Scaling: it is the property is found in cantor set, Sierpinski gasket for example and all of the fractal forms, so that a small part of the form is identical or similar to the whole but with smaller scale and in some true fractal forms this can happen till infinity.

Holism: This quality is evident in the creation way of fractal forms and also in the fractal forms generated by IFS, as the fractal form is based on a creation concept that controls the structure of the shape or form and controls its growth form, so that part of the form reflects its creation concept [6: P15].

Complexity and Fractal Dimension: Cantor's curve and Peano's space filling curve did not fit the patterns of Euclid and Newton, and they were regarded as monsters as they had a glimpse of infinity and they could fill the space or their length can increase til infinity while taking almost the same area. So measuring their dimension seemed to be impossible by using classical ways. so there are three different ways to determine the dimension of a fractal shape: Self-similarity dimension (Ds), measured dimension (d), box counting dimension $(\mathrm{Db})$, box counting dimension is the best to measure the complexity in interior design and architecture. [4: P23]

\section{Creating Fractal Shapes using Iteration and feedback process:}

Most of the fractals can be created by using the "iteration and feedback" system throughout some steps, in which the input of one step is the output of the previous step. Which is used to create self-similar forms on different scales. (see Figure 3).

\section{The human connection with nature and natural structures}

Natural materials and shapes are all around us, also people spend much time in gardens, sea shores, dessert environment which comes from their appreciation to nature. It has been proven that the natural forms are essential for the well-being of the human mental, physical health, that explains the appearance of nature and natural forms in society, cultural preferences, creations also in the way we choose materials, colors and motifs. Also using these natural objects and forms in Interior and furniture design is helping humans to be always connected with nature. [6: P24]. connected with nature. [6: P24].

\section{Characteristics of ecosystems [5: P64].}

Christopher Alexander identified fifteen properties or structural characteristic of nature and ecosystems.

1-Levels of scale: Cost lines and river banks, taking for example the Pacific side of North America, you'll notice a jagged shape and by looking at a smaller piece of the cost you'll notice similar zigzags. Many other natural forms have that feature [5: P17].

2-Strong centers: that most of the natural organisms grows outwards around a center [6: P64].

3-Boundaries: when different natural systems approaches each other, a boundary zone is created, this boundary can be developed to have a distinct entity with its own characteristics [6: P64]. 

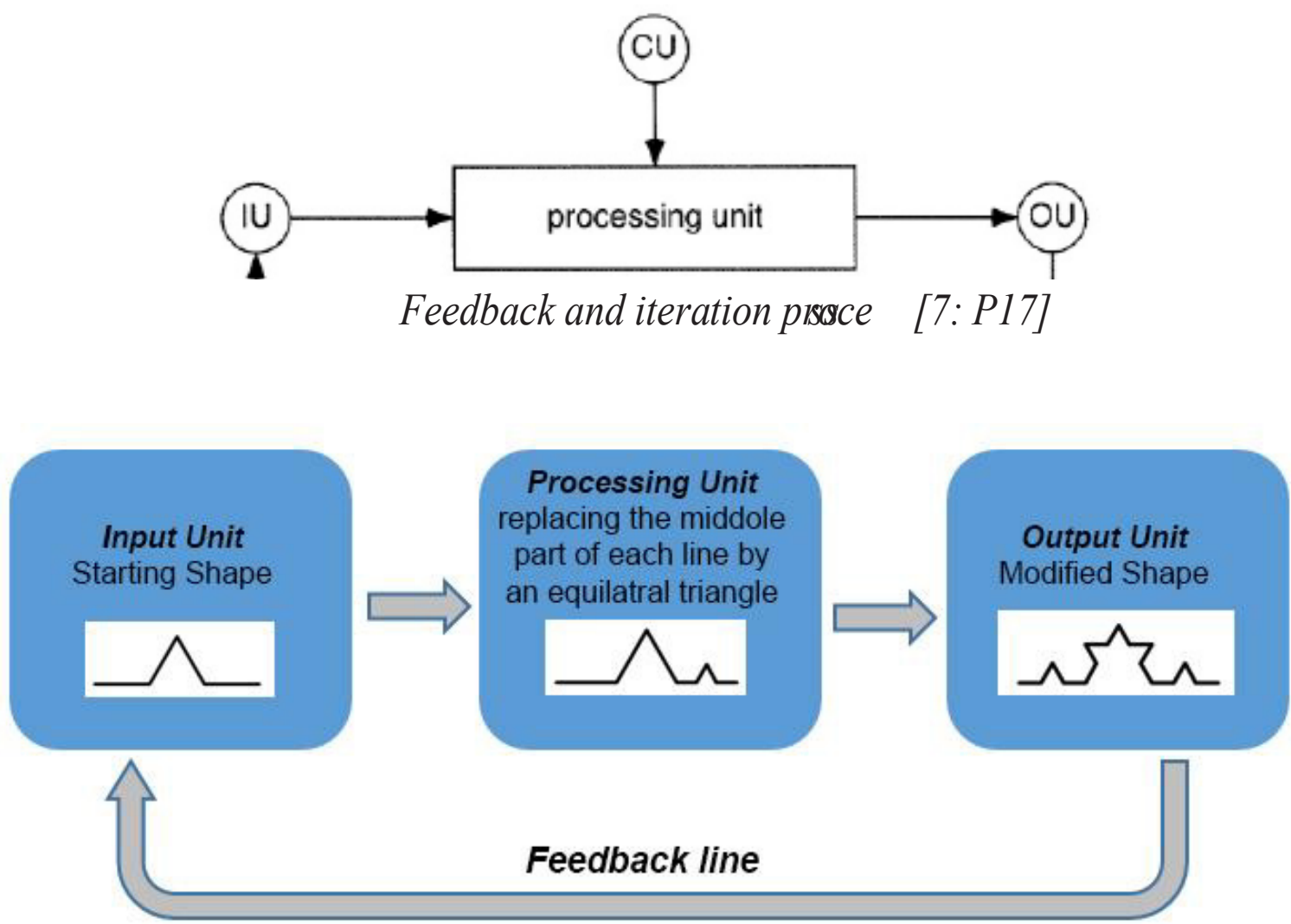

Figure 3: Feedback and Iteration process applied on Koch curve [7] - edited by researcher

4- Alternating repetition: occurs in natural forms repetition can happen radially with special and different sequences [6: P65].

5- Positive space: the natural form shows itself not only by its physical form but also by the space between its parts.

6- Good shape: this quality is wildly spread in natural forms, and is considered as the first inspiration to mankind.

7- Local symmetries: this quality is evident in ecosystems and can be found in star fish as a radial symmetry or a symmetry along a longitudinal axis such as in a butterfly wing [15].

8- Deep interlock and ambiguity: can be found in the interaction of two natural systems along a large surface

9- Contrast: it is the thing and it's opposite, these oppositions reinforces each of

the opposites. It can be in light and dark, life and death, existence or nonexistence.
10- Gradients: can be in shapes, colors or size, it can be found in the sky color or gradual growth of a plant. 11-Roughness: most of the natural structures is not smooth; clouds are not spheres; mountains are not cones.

12-Echoes: found in forest trees

13-The void: smaller structures tend to appear around the edge of larger structures, like the galaxies are surrounded by a very complicated structures.

14- Simplicity and inner calm: each part of the ecosystem is the simplest one consistent with its conditions.

15- Non-separateness: systems cannot be totally separated from each other.

7. Ecosystems and fractal geometry

Thinking about fractal images or forms does not mean static objects, but there are many living examples of fractal geometry found in nature, and not necessarily derived from a complicated process but simple processes can lead to a very complicated result, which is also the concept of Chaos [7: P16]. 
Benoit Mandelbrot in his book "the fractal geometry of nature" he illustrates the difference between the Euclidean geometry and fractal geometry in describing natural forms in the following way "Why is geometry often called cold and dry? One reason lies in its inability to describe the shape of a cloud, a mountain, a coastline, or a tree. Clouds are not spheres, mountains are not cones, coastlines are not circles, and bark is not smooth, nor does lightning travel in a straight line" [4: P5].

Some constructions in which Cantor, Sierpinski, Benoit Mandelbrot and others had created held the clues to understanding the patterns found in ecosystems in a visual sense [7: P129].

7.1 Using Fractals to imitate natural forms:

Using technology and computers, it is now possible to create all sorts of realistic Fractal Forgeries, images of natural scenes and with more accuracy (as shown in Figure 4).

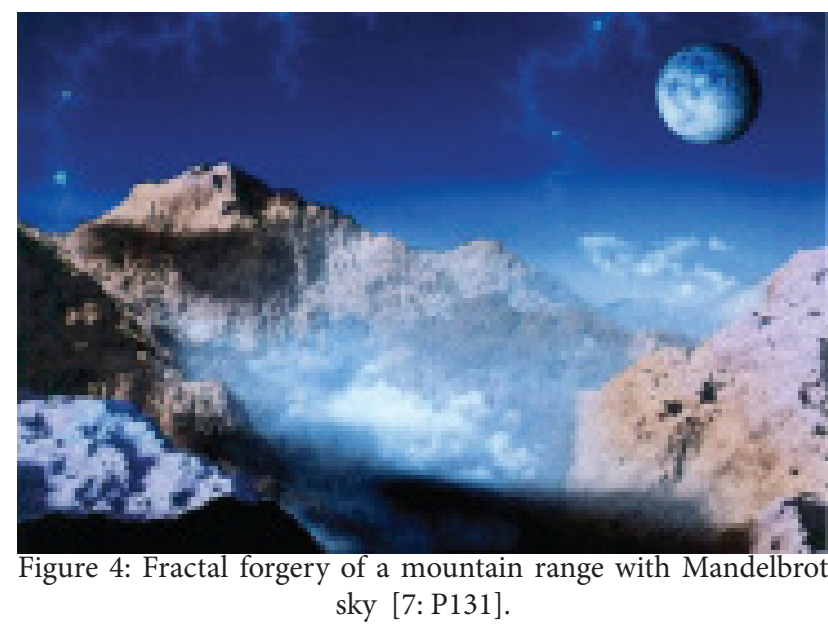

Some of the fractal forms that resembles the natural ones can be created also by using the feedback and iteration systems, by applying same action on the result of the previous step and so on. The next example (as shown in Figure 5) shows how we can create fractals that looks like natural plants using iteration and feedback system. Steps for creating fractal geometric shape using Euclidian geometry [7: P125]:

Step 1: Draw a square.

Step 2: Attach a right triangle to one of its sides along its hypotenuse (here with two equal sides). Step 3: Attach two squares along the free sides of the triangle.
Andby repeatingthesamestepson thenew squares in the followingstepswewillfind theshapein(Figure5)created And after doing some modifications to the previous shapes by replacing the equilateral triangle with a right angled triangle and repeating the previous steps till infinity the ending result will resemble the natural forms (as shown in Figure 6).

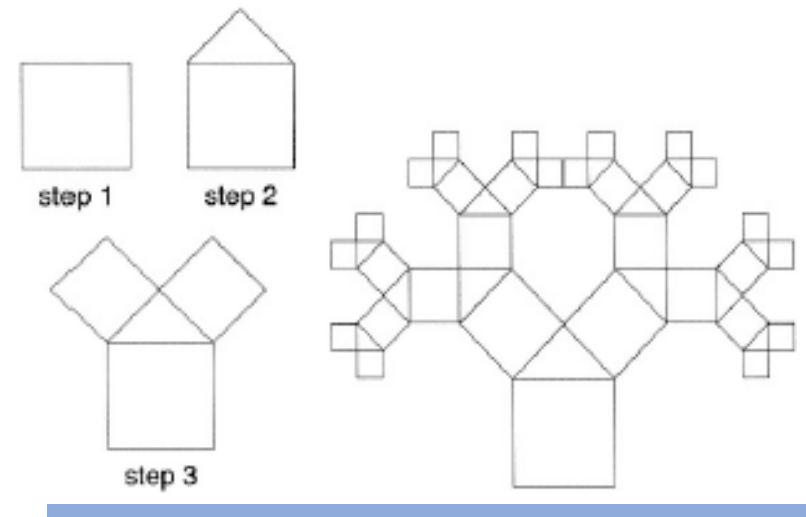

Figure 5: shows feedback and iteration system steps for creating fractal shape [7: P125].

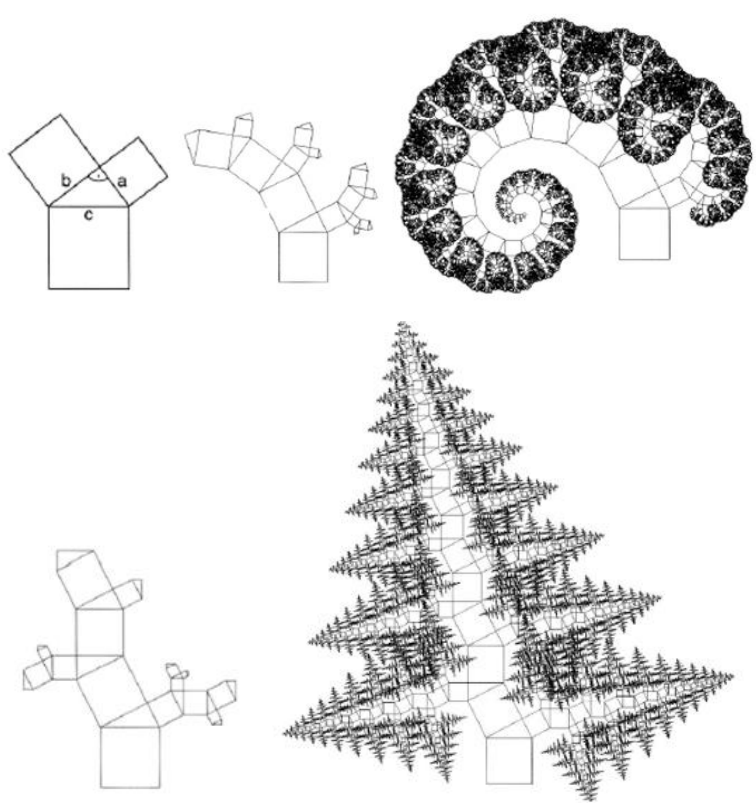

Figure 6: shows steps of creating fractal forms that resembles natural plants. [7: P124,126]

By using MCRM the "Multiple Reduction Copy Machine". This machine provides a good metaphor for what is known as "Deterministic Iterated Function Systems (IFS)" in mathematics, the copy machine takes an image as input. It has several independent lens systems, each of which reduces the input image and places it somewhere in the output image [7: P217]. The assembly of all reduced copies in some pattern is 
finally produced as output. Using this system we can create a fractal fen (Barnsley's Fen) By starting with a rectangular image attached to it a St. line, which represents the stem, by transforming the rectangle and the St. line to smaller copies, and placing them in relation to the main rectangle, then by applying the same steps to the 3 rectangles and repeating the process till infinite no. of steps, then replacing those rectangles with a plant leaf shape, the ending result will be a fractal fen (as shown in Figure 7) [7: P243].
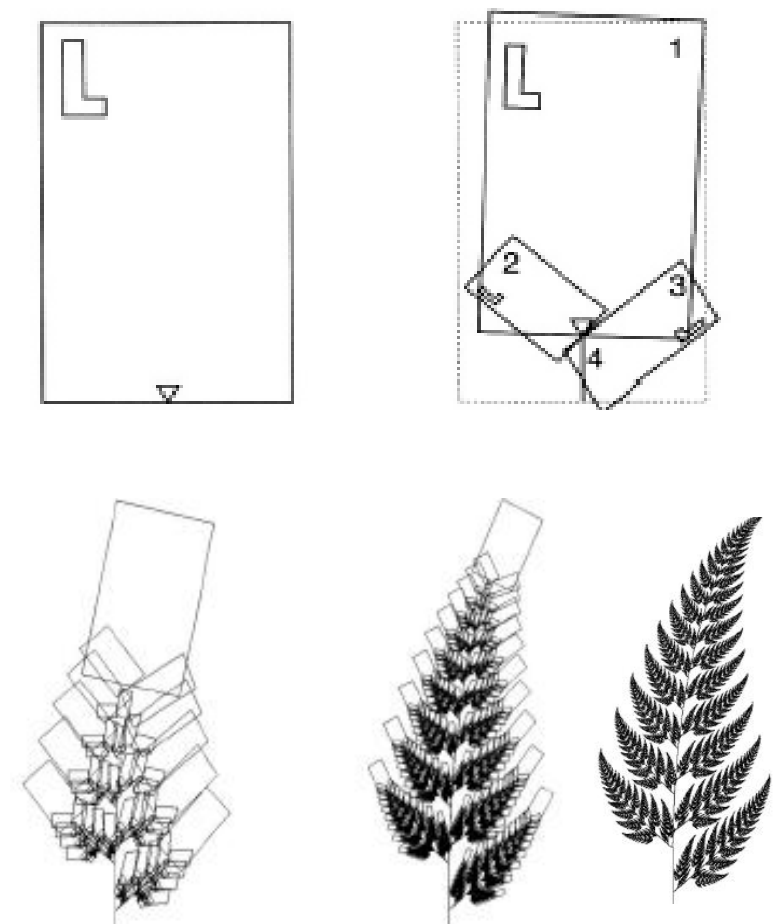

Figure 7: showssteps of creatingfractalfen usingIFS [7:242,243,244]

8. Fractal geometry relation with Interior Design and Architecture

Fractal concept can be used in Interior design and architectural compositions by showing interesting levels of details as we approach the building or the interior space, as there should always be another smaller-scale of details that describes and completes the whole composition. As this was well done in Frank Lloyd Wright's houses [4: P5]. One of the examples that shows successive details, and self-similarity is the Federation square buildings, where the interior and exterior walls are cladded by 6 different materials using pinwheel tiling design (as shown in Figure 8-a). The window Robie's house by Frank Lloyd wright, shows a fractal design, where self-similarity, scale and details appear in the design (as shown in Figure 8-c), also Frank Lloyds wright shows fractal design in the space planning of the main floor of Palmer's house, where his design depends on the triangles creating spaces that looks similar to each other with different scales as shown in Figure 8-e ). By going back in historical monuments, we'll find that most of the Gothic and Islamic designs include the characteristics of Fractal shapes such as the floor design of Gothic Cathedral Anagni, where the floor tiles look like Sierpinski triangles as shown in Figure 8-b), also in the Islamic house of Borujerdi in Iran the ceiling shows self-similar design with different scales, also the architectural openings and arches are self-similar including fine details that appears when you get closer as shown in Figure 8-f). some of the modern furniture got fractal shapes such as shown in( Figure 8-d)

9. "Nature" and "Interior Design, Furniture design and Architectural design"

Connection with nature has been proven to be essential to human mental, emotional and physical health. This has been rooted in human's perception of aesthetic forms, and utilizing natural forms has been used by designers and architects throughout history [5: P53]. One of the configurations in nature is the golden ratio of 1.618 , it has been proven that it was used widely in Interior design, furniture design and architectural design (as shown in Figure 9),

Ancient Egyptian temples were based on showing the impact of nature in their artifacts, they used mathematical models based on astrological studies to design their temples. They used natural elements in their motifs like plants, sun, ... etc (as shown in Figure 10-a). The Greek temple architecture of primary forms constituted the purity of place where gods resided. Roman architecture expresses the integration with nature through using circular array of coffers with diminishing size up to the apex opening which represents the universe and the presence of God (as shown in Figure 10-b). Hindu temples reflect their connectivity with nature, the mountain is an archetype in the Hindu universe epitomizing the center of the universe (as shown in Figure 10-c). Gothic architecture conveyed an organic fee and sense of life through the architectural elements in gothic cathedrals, down the aisles the columns shafts radiates into intricate fan-vaulting tracery that gives the feeling of walking in a path of lined trees with branches and leaves (as shown in Figure 10-d) [6:P70-71]. Islamic art and architecture was influenced by nature starting from the calligraphy, plant 


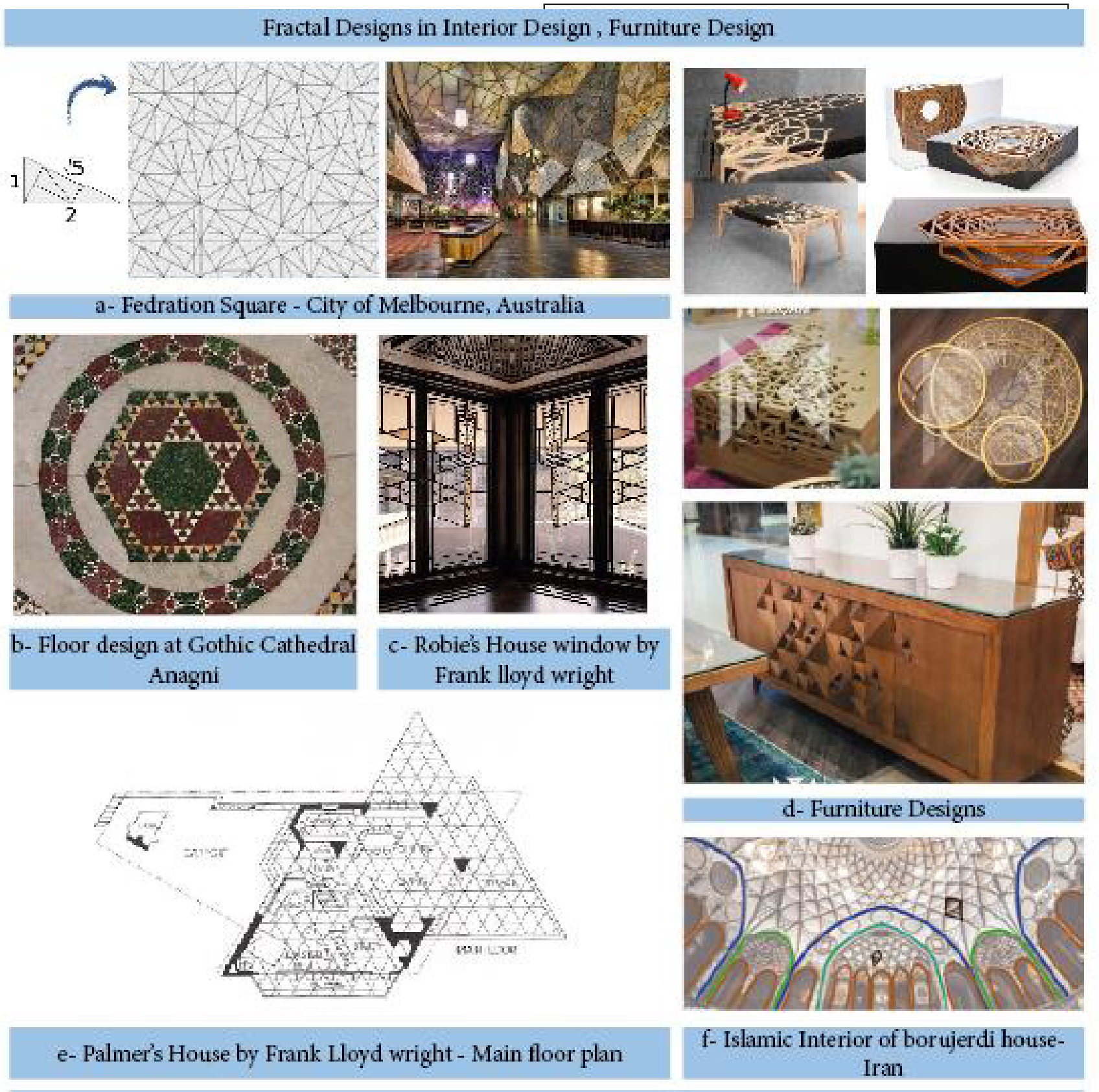

Figure 8: shows examples of fractal shapes in interior design, furniture design and architecture throughout history [18] [33] [41] [42].

motifs, up to the geometric ornaments and motifs that was all affected by nature and Islamic beliefs (as shown in Figure 10-e). Renaissance architecture had the unity quality that was present in nature, where the whole determines the structure of the parts. Baroque churches at the end of the nineteenth century exhibited organic aspects in their design by using curves and shapes that feels organically alive (as shown in Figure 10-f). Art Nouveau integrated organic form as a functional component, also by using floral motifs and ornaments. Gauadi's work at Sagrada Familia shows the organic structure and nature's effect on his designs (as shown in Figure 10-g). Organic architecture was promoted by Hugo Harring and Rudolf Steiner. Hugo Harring followed the concept that the form unfolds from its function, Rudolf Steiner believed that creating remarkable design depends on the ability to recognize order, harmony and meaning of nature by applying hidden laws of nature [6: P71-72]. 


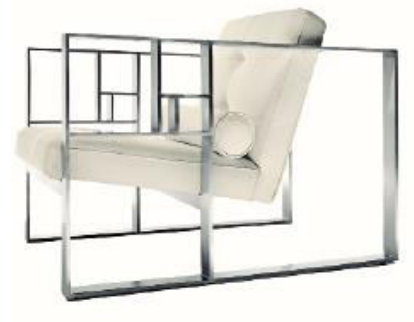

a- Chair design with golden section Armrest

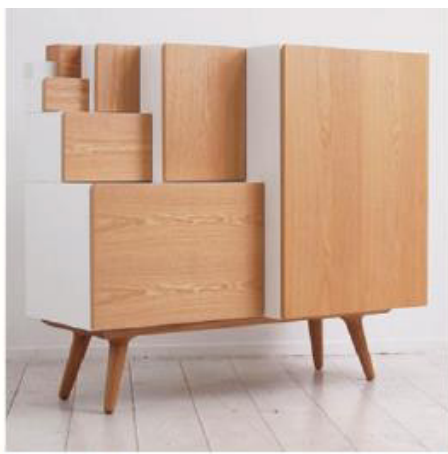

b- Golden section in a cabinet design

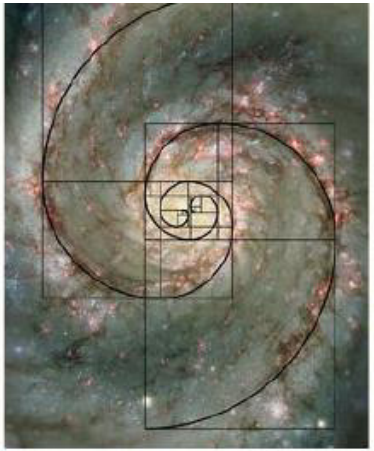

c- Golden section in cosmology

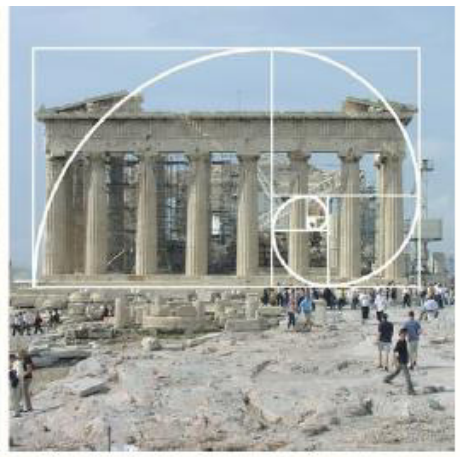

d- Parthenon Golden section

Figure 9: showing golden ratio In nature, Architectural design and furniture design [26] [35] [43] [44]

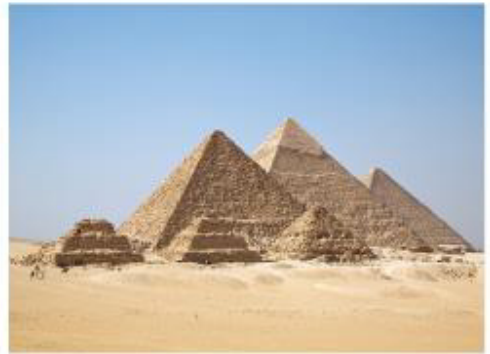

a- Pyramids - Egypt

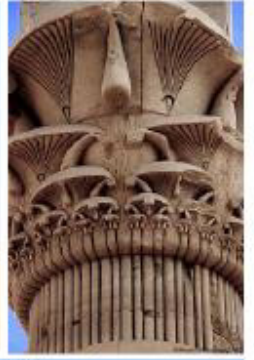

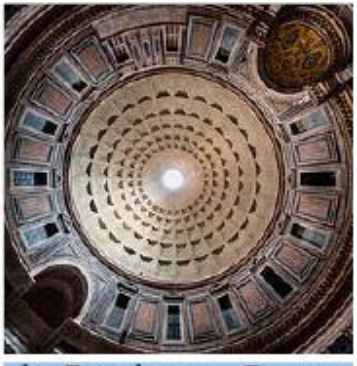

b- Pantheon - Rome

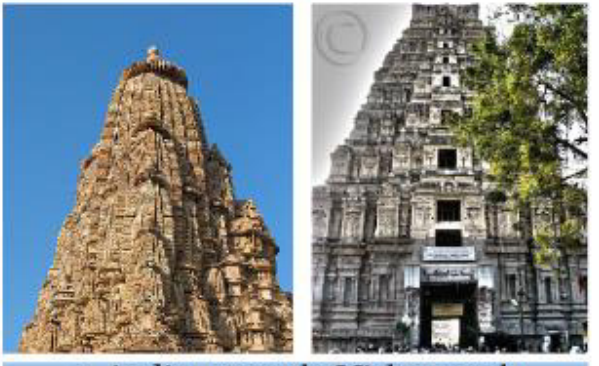

c-indian temple Vishwanath

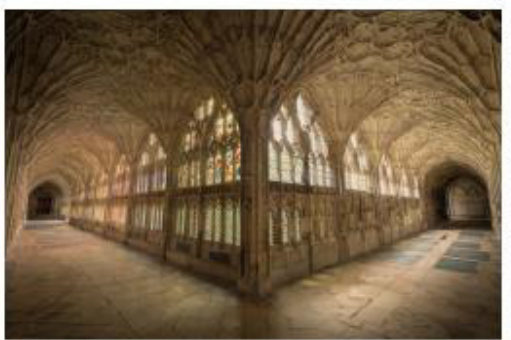

d-Gloucester Cathedral - UK

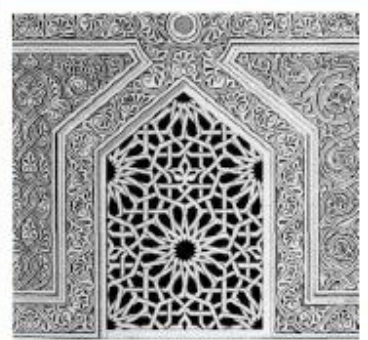

e- Ibn Tulon window - Egypt

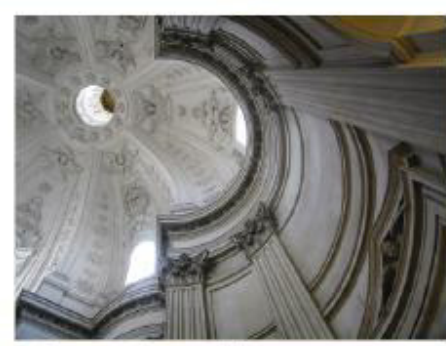

f- Sant'Ivo alla Sapienza Italy

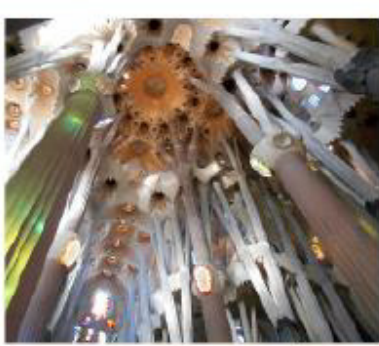

g- Sagrada Familia Spain

Figure 10: Examples of interior and architectural designs that are inspired by Nature [13] [16] [17] [19] [22]

\section{Analytical Work}

10.1 Common qualities between fractal form, Natural form, (Interior, Furniture and Architectural form) A lot of common characteristics were found between classical Fractal geometry and Nature, also are found between nature and design, fractal shapes and design as shown in the below table which tries to connect between the three fractals, Nature and design. 


\begin{tabular}{|c|c|c|c|}
\hline $\begin{array}{l}\text { Character } \\
\text { istics }\end{array}$ & Fractal Geometry & Ecosystems & $\begin{array}{l}\text { Interior Design, Furniture } \\
\text { design \& Architecture }\end{array}$ \\
\hline $\begin{array}{l}\text { Self- } \\
\text { similarity }\end{array}$ & $\begin{array}{l}\text { In some shapes, self- } \\
\text { similarity can be strict } \\
\text { all smaller parts are a } \\
\text { typical copy of the whole } \\
\text { shape such as the one } \\
\text { found in Koch curve or } \\
\text { Sierpinski gasket. }\end{array}$ & $\begin{array}{l}\text { In nature it is the process of } \\
\text { decomposing a natural object } \\
\text { into smaller clusters can be } \\
\text { carried through for a limited } \\
\text { no of stages which is about } \\
\text { three or four stages [7: P63]. } \\
\text { lige } \\
\text { [29] =Edited by researcher } \\
\text { Snow Flakes shows self- } \\
\text { similarity as it has diagonal } \\
\text { lines, each line radiates } \\
\text { smaller lines, each smaller } \\
\text { line radiates smaller lines; so } \\
\text { smaller parts are similar to } \\
\text { larger parts. }\end{array}$ & 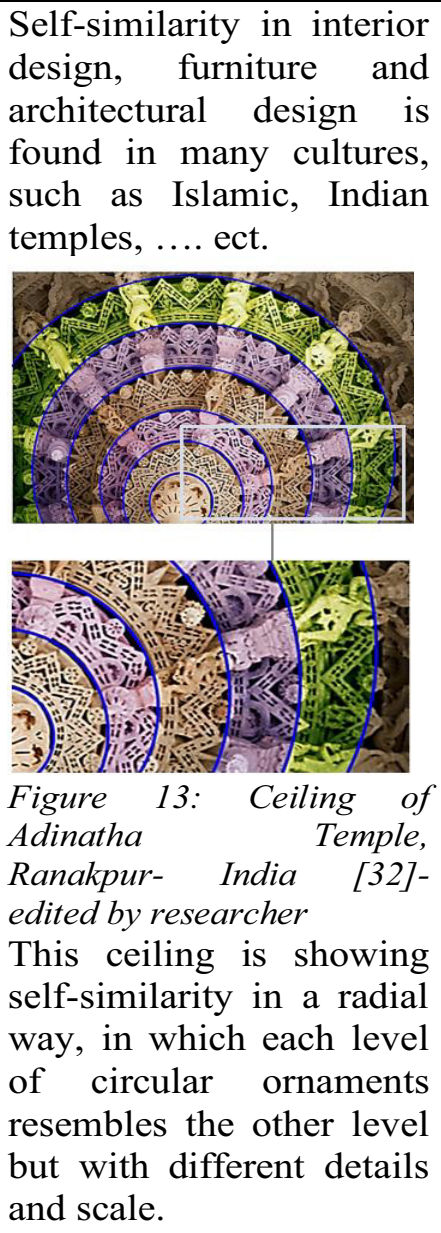 \\
\hline Scale & $\begin{array}{l}\text { In fractal shapes, the } \\
\text { scale quality is evident, } \\
\text { and by zooming in till } \\
\text { infinity we can still find } \\
\text { smaller copies of the } \\
\text { whole shape. }\end{array}$ & $\begin{array}{l}\text { Figure 15: Fern leaf [20]- } \\
\text { edited by researcher } \\
\text { Each leaf of this plant } \\
\text { contains other leaflets similar } \\
\text { to the whole leaf but with }\end{array}$ & $\begin{array}{l}\text { In architecture scale } \\
\text { quality is found, but to a } \\
\text { certain level. } \\
\text { Figure 16: Hindu temple } \\
\text { design [6] } \\
\text { The temple consists of } \\
\text { successive halls that } \\
\text { gradually gets larger from } \\
\text { entrance hall till the } \\
\text { "Garbhagrha hall", also } \\
\text { the towers gets gradually }\end{array}$ \\
\hline
\end{tabular}




\begin{tabular}{|c|c|c|c|}
\hline $\begin{array}{l}\text { Character } \\
\text { istics }\end{array}$ & Fractal Geometry & Ecosystems & $\begin{array}{l}\text { Interior Design, Furniture } \\
\text { design \& Architecture }\end{array}$ \\
\hline & $\begin{array}{l}\text { researcher } \\
\text { Small triangles in } \\
\text { Seirpinski gasket is a } \\
\text { scaled down copy of the } \\
\text { whole shape. }\end{array}$ & smaller scale. & $\begin{array}{l}\text { higher, so each tower is a } \\
\text { smaller copy of the } \\
\text { successive tower. }\end{array}$ \\
\hline $\begin{array}{l}\text { Roughnes } \\
\text { s \& \& } \\
\text { successiv } \\
\text { e details }\end{array}$ & $\begin{array}{l}\text { In most of the fractal } \\
\text { shapes, the edges are not } \\
\text { smooth, it shows a } \\
\text { cascade of details once } \\
\text { you get closer. } \\
\text { Figure 17: Minkowski curve } \\
\text { 4: P12]. } \\
\text { By zooming in to the } \\
\text { fractal shape, more } \\
\text { details will appear, this } \\
\text { can happen till infinity. } \\
\text { (18) } \\
\text { Figure 18: fractal shape } \\
\text { with rough edges [21] }\end{array}$ & $\begin{array}{l}\text { Roughness is found in many } \\
\text { objects and shapes in nature, } \\
\text { as once you get closer you'll } \\
\text { find more details appear. } \\
\text { Figure 19: Mountain in } \\
\text { Mountain surfaces are not } \\
\text { smooth, it is rough and got } \\
\text { details, once you get closer } \\
\text { you'll notice smaller details } \\
\text { of stones and rocks. } \\
\text { The fractal profiles of } \\
\text { mountains } \\
\text { can take many forms some } \\
\text { taller, some flatter, but all } \\
\text { with the same repetition of } \\
\text { shape at different scales.[1: } \\
\text { P67] }\end{array}$ & $\begin{array}{l}\text { Roughness is used in } \\
\text { design by using rough } \\
\text { materials like raw stones, } \\
\text { or by carving motifs and } \\
\text { patterns. } \\
\text { Figure 20: Louis Sullivan } \\
\text { ornamental design on a } \\
\text { building [6] } \\
\text { The wall design was } \\
\text { decorated by these } \\
\text { carvings in which a lot of } \\
\text { curved details that cannot } \\
\text { appear from a distance, } \\
\text { but closer there are a lot } \\
\text { of details found. }\end{array}$ \\
\hline $\begin{array}{l}\text { Strong } \\
\text { centers }\end{array}$ & $\begin{array}{l}\text { Many of the fractal } \\
\text { shapes are formed } \\
\text { arround a center which } \\
\text { can be called an attactor. } \\
\text { Figure 21: Mandelbrot Set } \\
\text { [8: P202]. } \\
\text { In Mandelbrot set smaller } \\
\text { copies of the set are } \\
\text { surrounding the main }\end{array}$ & $\begin{array}{l}\text { In nature many of the shapes } \\
\text { are central or grows about a } \\
\text { center. } \\
\text { Figure 22: Spider home [38] } \\
\text { The concept of strong centers } \\
\text { is found in the spider home, } \\
\text { as it got radial lines and } \\
\text { circles with one center. }\end{array}$ & $\begin{array}{l}\text { In design human } \\
\text { implmented natural } \\
\text { shapes, and nature is full } \\
\text { of centered shapes shuch } \\
\text { as roses. } \\
\text { Figure 23: Chartres } \\
\text { Cathedral rose window [11] } \\
\text { Gothic windows are } \\
\text { inspired from roses and is }\end{array}$ \\
\hline
\end{tabular}




\begin{tabular}{|c|c|c|c|}
\hline $\begin{array}{l}\text { Character } \\
\text { istics }\end{array}$ & Fractal Geometry & Ecosystems & $\begin{array}{l}\text { Interior Design, Furniture } \\
\text { desion \& Architecture }\end{array}$ \\
\hline & large set. & & $\begin{array}{l}\text { called rose windows, it } \\
\text { got it's leafs around one } \\
\text { center with lots of details. }\end{array}$ \\
\hline $\begin{array}{l}\text { Boundari } \\
\text { es }\end{array}$ & $\begin{array}{l}\text { Fractal shapes got their } \\
\text { boundaries as some of } \\
\text { them can grow really fast } \\
\text { and the space they } \\
\text { occupy grow really slow. } \\
\text { Figure } 24: \text { Peano Curve [6: } \\
\text { P3]. } \\
\text { Some fractals like peano } \\
\text { curve does not exceed its } \\
\text { boundareis, by repeating } \\
\text { the process } \\
\text { substitution, the space } \\
\text { between lines is filled } \\
\text { without expanding its } \\
\text { area. }\end{array}$ & $\begin{array}{l}\text { Figure 25: Boundaaries in a } \\
\text { solid-liquid relationship [34] } \\
\text { An example of boundaries in } \\
\text { nature, is the relation between } \\
\text { two different media such as } \\
\text { liquid and solid. }\end{array}$ & $\begin{array}{l}\text { In interior design or } \\
\text { Architecture, the } \\
\text { boundaries can be done } \\
\text { by lines, walls or adding } \\
\text { different materials that } \\
\text { acts as a boundary. }\end{array}$ \\
\hline $\begin{array}{l}\text { Alternati } \\
\text { ng } \\
\text { repetition }\end{array}$ & $\begin{array}{l}\text { Figure 27: Mandelbrot set } \\
\text { [1] } \\
\text { In Mandelbrot set, and } \\
\text { color depends on how } \\
\text { numbers at in the } \\
\text { equation givin the } \\
\text { different shapes found in } \\
\text { the set revealing yet more } \\
\text { fractal structures, } \\
\text { producing these baroque } \\
\text { spirals. }\end{array}$ & $\begin{array}{l}\text { Repititions can be found in } \\
\text { nature, some of them are } \\
\text { following fibonacci series in } \\
\text { reptition such as sun flower } \\
\text { seeds. } \\
\text { Figure 28: Sun flower [1] } \\
\text { The spiral arrangement of } \\
\text { floret heads and seeds in a } \\
\text { sunflower follows the } \\
\text { Fibonacci sequence. }\end{array}$ & $\begin{array}{l}\text { In design reptitions are } \\
\text { used variously. } \\
\text { I? } \\
\text { Figure 29: Floor design at } \\
\text { ran Marco [12] } \\
\text { repetitions are used in } \\
\text { floor designs in Gothic } \\
\text { periods. }\end{array}$ \\
\hline $\begin{array}{l}\text { Positive } \\
\text { space }\end{array}$ & $\begin{array}{l}\text { Fractals have interesting } \\
\text { designs and shapes } \\
\text { occupying the space }\end{array}$ & $\begin{array}{l}\text { In nature the flow of liquids } \\
\text { in different denesties can } \\
\text { result in shapes with inspiring } \\
\text { designs. }\end{array}$ & $\begin{array}{l}\text { Using ceiling design with } \\
\text { posisitive spaces between } \\
\text { columns and ceiling } \\
\text { bricks. }\end{array}$ \\
\hline
\end{tabular}




\begin{tabular}{|c|c|c|c|}
\hline $\begin{array}{l}\text { Character } \\
\text { istics }\end{array}$ & Fractal Geometry & Ecosystems & $\begin{array}{l}\text { Interior Design, Furniture } \\
\text { design \& Architecture }\end{array}$ \\
\hline & $\begin{array}{l}\text { Figure 30: Part of } \\
\text { Mandelbrot set [9: P392]. }\end{array}$ & $\begin{array}{l}\text { Figure 31: Turbulence flow of a } \\
\text { dye injected in a cylindrical } \\
\text { shape tube full of liquid [2] }\end{array}$ & $\begin{array}{l}\text { Figure 32: aisle of Gothic } \\
\text { cathedral having column } \\
\text { shafts radiating into fan- } \\
\text { vaulting tracery like trees } \\
\text { [6]. }\end{array}$ \\
\hline $\begin{array}{l}\text { Good } \\
\text { shape }\end{array}$ & $\begin{array}{l}\text { Although fractals was a } \\
\text { mathematical discovery, } \\
\text { but it was found that it } \\
\text { got an athethitic appeal, } \\
\text { which made it inspiring } \\
\text { for designers. } \\
\text { Figure 33: Fractal spirals } \\
\text { [23] }\end{array}$ & $\begin{array}{l}\text { (iinfris } \\
\text { Figure 34: Spirals in natural } \\
\text { shapes [5: P105]. }\end{array}$ & $\begin{array}{l}\text { By getting inspired from } \\
\text { nature, man learned from } \\
\text { nature how to design } \\
\text { good shapes with good } \\
\text { ratios. }\end{array}$ \\
\hline $\begin{array}{l}\text { Local } \\
\text { Symmetri } \\
\text { es }\end{array}$ & $\begin{array}{l}\text { Symmetries are found in } \\
\text { most of the fractal shapes, } \\
\text { some of them are } \\
\text { symmetrical arround one } \\
\text { axis such as Mandelbrot } \\
\text { set, and some are } \\
\text { symmetrical around more } \\
\text { than one axis such as } \\
\text { Koch island. } \\
\text { Figure 36: Symmetry in } \\
\text { Koch snowflake [7: P88]- } \\
\text { edited by researcher }\end{array}$ & $\begin{array}{l}\text { In nature particles, grains, } \\
\text { rocks, fluids and living } \\
\text { tissues can arrange } \\
\text { themselves into regular and } \\
\text { geometrical patterns by } \\
\text { applying its own rules of how } \\
\text { their parts behave. Symmetry } \\
\text { is the key of understandin } \\
\text { how such patterns appear. } \\
\text { Figure 37: Fivefold symmetry is } \\
\text { often favored by echinoderms } \\
\text { such as starfish and sea urchins [1] }\end{array}$ & $\begin{array}{l}\text { In Interior, furniture or } \\
\text { architectural design, the } \\
\text { local symmetris has been } \\
\text { used widely. } \\
\text { Figure 38: The Pantheon in } \\
\text { Rome dome from inside [6] } \\
\text { Symmetry found in the } \\
\text { arrayed design of the } \\
\text { dome. }\end{array}$ \\
\hline
\end{tabular}




\begin{tabular}{|c|c|c|c|}
\hline $\begin{array}{l}\text { Character } \\
\text { istics }\end{array}$ & Fractal Geometry & Ecosystems & $\begin{array}{l}\text { Interior Design, Furniture } \\
\text { design \& Architecture }\end{array}$ \\
\hline $\begin{array}{l}\text { Nested } \\
\text { quality \& } \\
\text { Deep } \\
\text { interlock }\end{array}$ & $\begin{array}{l}\text { Fractals are full of } \\
\text { nesting quality, in some } \\
\text { cases nesting is very } \\
\text { strict. }\end{array}$ & $\begin{array}{l}\text { In nature shapes of same } \\
\text { material are nested togeather, } \\
\text { wood barks, treel leaves, } \\
\text { mountains, honeycomb... etc. }\end{array}$ & $\begin{array}{l}\text { Nesting quality is found } \\
\text { in ancient egyptian } \\
\text { drawings on a temple. } \\
\text { cosmology (Geb the earth, } \\
\text { enclosed by Shu, space, } \\
\text { enclosed by Nut, te stellar } \\
\text { canopy) [5: P134]. } \\
\text { Figure 44: Nested coffee } \\
\text { tables set [25] } \\
\text { Nesting can also be found } \\
\text { in furniture, where } \\
\text { furniture pieces are } \\
\text { nested togheather for } \\
\text { aesthetic quality and } \\
\text { functional quality. }\end{array}$ \\
\hline Contrast & $\begin{array}{l}\text { Contrast in fractals for } \\
\text { example can be found in } \\
\text { the existence and absence } \\
\text { of } \\
\text { Figure something, } \\
\text { triangle [6] } \\
\text { In this triangle, the } \\
\text { absence of the black } \\
\text { triangles is what makes } \\
\text { this shape. }\end{array}$ & $\begin{array}{l}\text { Nature is full of contrast in } \\
\text { shapes, colors, material, light } \\
\text { and darkness. } \\
\text { Zibra lines got contrast } \\
\text { between white and black. }\end{array}$ & $\begin{array}{l}\text { Contrast is an element } \\
\text { that is widely used in } \\
\text { interior design and } \\
\text { furniture, this contast can } \\
\text { be found in colors or } \\
\text { shapes, lights...etc. } \\
\text { Figure } 47: \text { the contrast in } \\
\text { light and darkness found in } \\
\text { the space where pots are } \\
\text { placed above each other }\end{array}$ \\
\hline
\end{tabular}




\begin{tabular}{|c|c|c|c|}
\hline $\begin{array}{l}\text { Character } \\
\text { istics }\end{array}$ & Fractal Geometry & Ecosystems & $\begin{array}{l}\text { Interior Design, Furniture } \\
\text { design \& Architecture }\end{array}$ \\
\hline & & & {$[5]$} \\
\hline \multirow[t]{2}{*}{ Gradients } & $\begin{array}{l}\text { Some fractals can } \\
\text { gradually change in size }\end{array}$ & $\begin{array}{l}\text { Gradients in nature can be } \\
\text { found in growing plants, } \\
\text { where there are some small } \\
\text { leaves or fruits, and some are } \\
\text { fully grown. } \\
\text { igure } 49 \text { : Cauliflower plant [1] } \\
\text { Cauliflower clusters shows } \\
\text { gradient sizes from large to a } \\
\text { very tiny size, also inside } \\
\text { each cluster there are smaller } \\
\text { clusters with gradual change } \\
\text { in size. }\end{array}$ & $\begin{array}{l}\text { It was found that some } \\
\text { old architectural } \\
\text { monuments followed the } \\
\text { ratios of nature. } \\
\text { Figure 51: Ratios in Ancient } \\
\text { egyptian Temple [5: P89] } \\
\text { Ancient egyptian temple } \\
\text { consists of successive } \\
\text { chambers, and their } \\
\text { length gradually scales } \\
\text { down with a ratio that } \\
\text { follows the fibbonacci } \\
\text { series. }\end{array}$ \\
\hline & & $\begin{array}{l}\text { Figure 50: the gradual change } \\
\text { in size of cactus plant parts [1] }\end{array}$ & $\begin{array}{l}\text { Figure 52: a cabinet with } \\
\text { gradient veneer design [27] }\end{array}$ \\
\hline Echoes & $\begin{array}{l}\text { Echoes in fractal shapes } \\
\text { are found in the faded } \\
\text { reptitition of details and } \\
\text { in graduation. } \\
\\
\text { Figure 53: Part of } \\
\text { Mandelbro Set [6:P9]. }\end{array}$ & $\begin{array}{l}\text { Echoes in nature are found in } \\
\text { the similar shapes, and the } \\
\text { extension in nature. } \\
\text { Figure 54: Snake skin (python } \\
\text { snake) [40] }\end{array}$ & $\begin{array}{l}\text { Echo in interior, furniture } \\
\text { or architectural design in } \\
\text { repeating similar shapes } \\
\text { or in the contiuity found } \\
\text { in the design lines or } \\
\text { shapes. } \\
\text { ald } \\
\text { Figure 55: Snake skin } \\
\text { models in African culture } \\
\text { [5: P44]. }\end{array}$ \\
\hline
\end{tabular}




\begin{tabular}{|c|c|c|c|}
\hline $\begin{array}{l}\text { Character } \\
\text { istics }\end{array}$ & Fractal Geometry & Ecosystems & $\begin{array}{l}\text { Interior D esign, F urniture } \\
\text { design \& Architecture }\end{array}$ \\
\hline $\begin{array}{l}\text { Simplicit } \\
\text { y and } \\
\text { inner } \\
\text { calm }\end{array}$ & $\begin{array}{l}\text { Fractals g ot simplicity in } \\
\text { the way creating } \mathrm{i} \text {, } \\
\text { fractals a re done by } \\
\text { simple s teps t hat resutls } \\
\text { in a v ery complicated } \\
\text { shapes. } \\
\text { Figure 56: Fractal tree [6]. } \\
\text { Heighway d ragon i } \mathrm{s} \\
\text { created by s imple steps } \\
\text { leading to a g ood s hape } \\
\text { of pattern. }\end{array}$ & $\begin{array}{l}\text { Figure 57: Acacia tree [28] } \\
\text { Acaria t ree shows branching } \\
\text { in } \mathrm{n} \text { ature. A v ery simple } \\
\text { concept and inner calm i s } \\
\text { found in its shape and how it } \\
\text { grows. }\end{array}$ & $\begin{array}{l}\text { Simplicity } \mathrm{i} \text { n interion } \\
\text { design and a rchitecture is } \\
\text { found in the simple lines, } \\
\text { the simple c oncept o } \\
\text { design, which makes the } \\
\text { inner calm of the design } \\
\text { evident to t he u ser of }\end{array}$ \\
\hline
\end{tabular}

Table no (1) showing the comparison between the charecteristics of Ecoststems and how it is found in fratal fractal eometry and interior design,furniture design and architecture - done by researcher.

10.2 Creating fractal shapes inspired from nature. By knowing the previous qualities and how it is found in natural forms and fractal forms, and by getting inspired from the natural five star and hexagons found in nature such as shown in (Figure 60). We can use it in creating patterns that can be used in interior and furniture design that has as self-similarity, scale, roughness, strong centers, local symmetry and nested quality.

Steps of creating fractal shape inspired from Nature. This shape in (Figure 61) was created by applying successive steps as follows:

Step 1: creating a pentagon with empty middle part. Step 2: repeating, rotating copies of the shape are created around a center point.

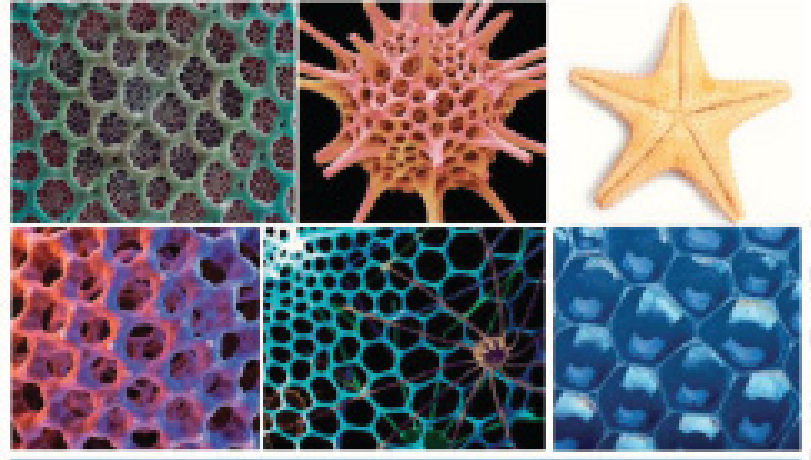

Figure 60: Natural shapes that has pentagons and five star shapes.[1]

Step 3: adding more copies of the pentagon Step 4: extending the outer lines a larger pentagon can be created. 


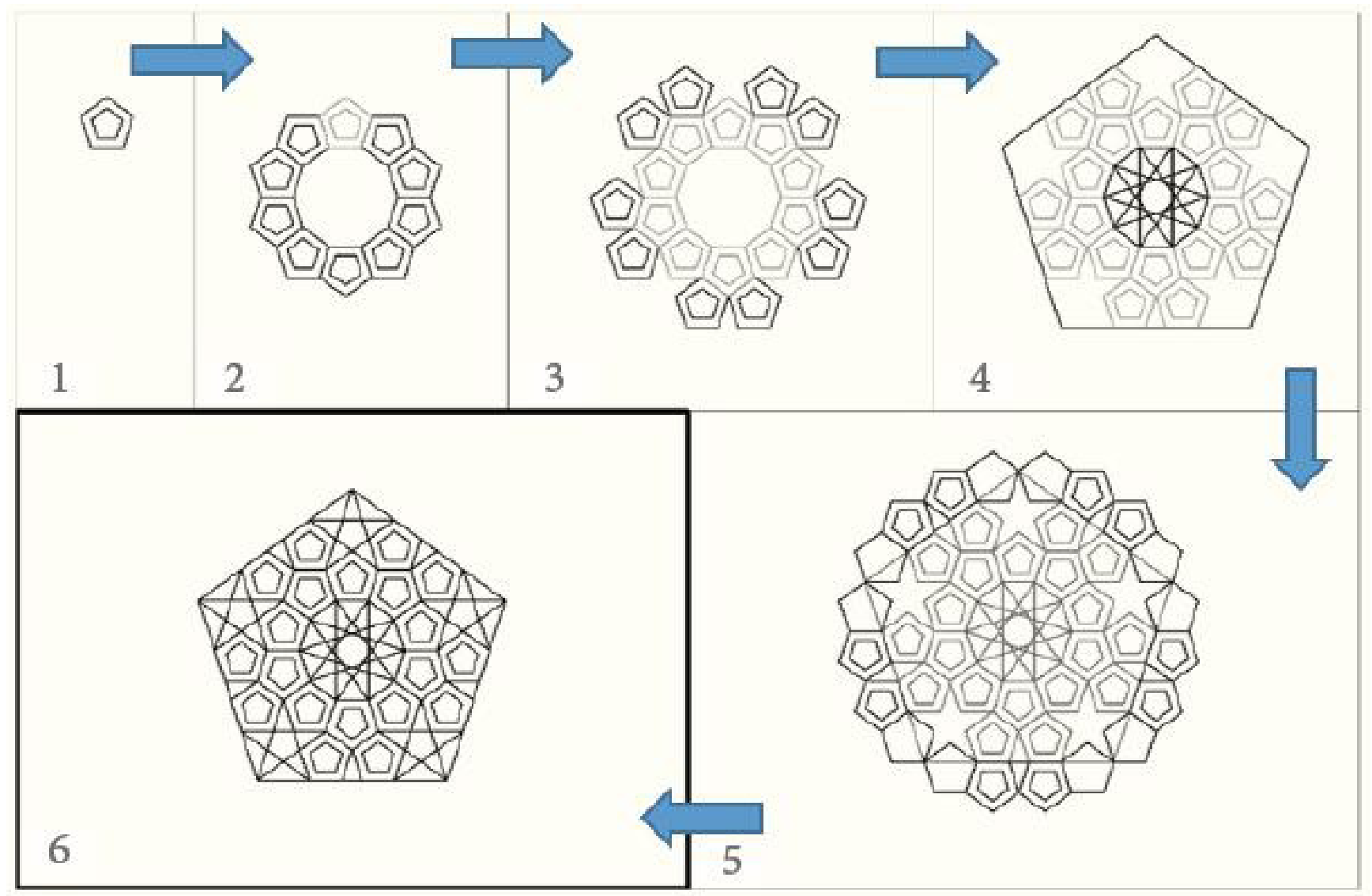

Figure 61: Steps of creating fractal shapes inspired from Nature- by researcher
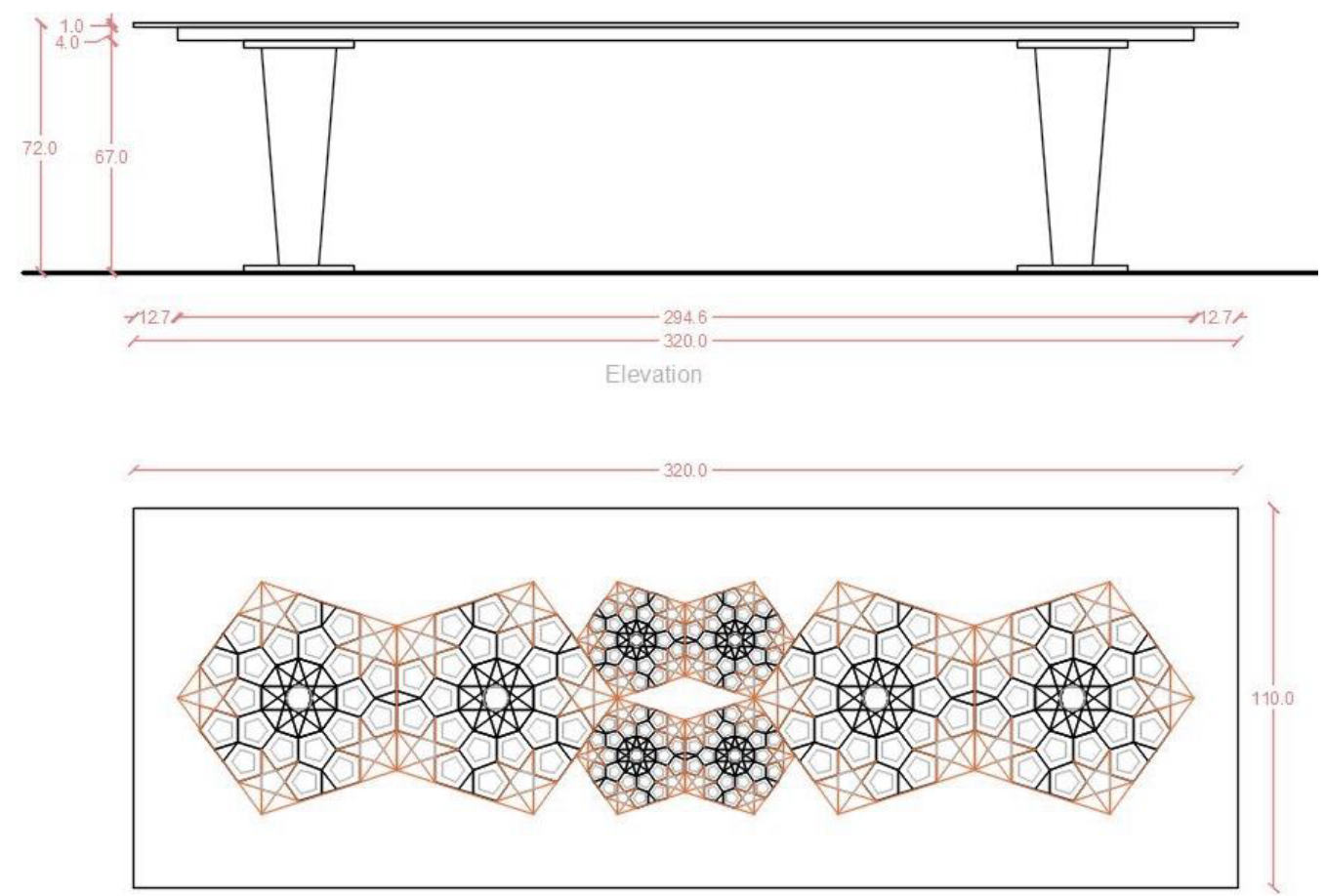

Figure 62: Using the created fractal shape in dining table design - by resarcher 
Step 5: adding more pentagons on the edges to complete the shape.

Step 6: removing excess lines so that 5 star shapes are created at the inner angles of the large pentagon.

By using the previous shape and creating small and large copies of itself, we can use it in the top design of a dining table such as shown in (Figure 62).

Also by using repeated copies of the pentagon, it can be used in the deign of a dining chair such as shown in (Figure 63).

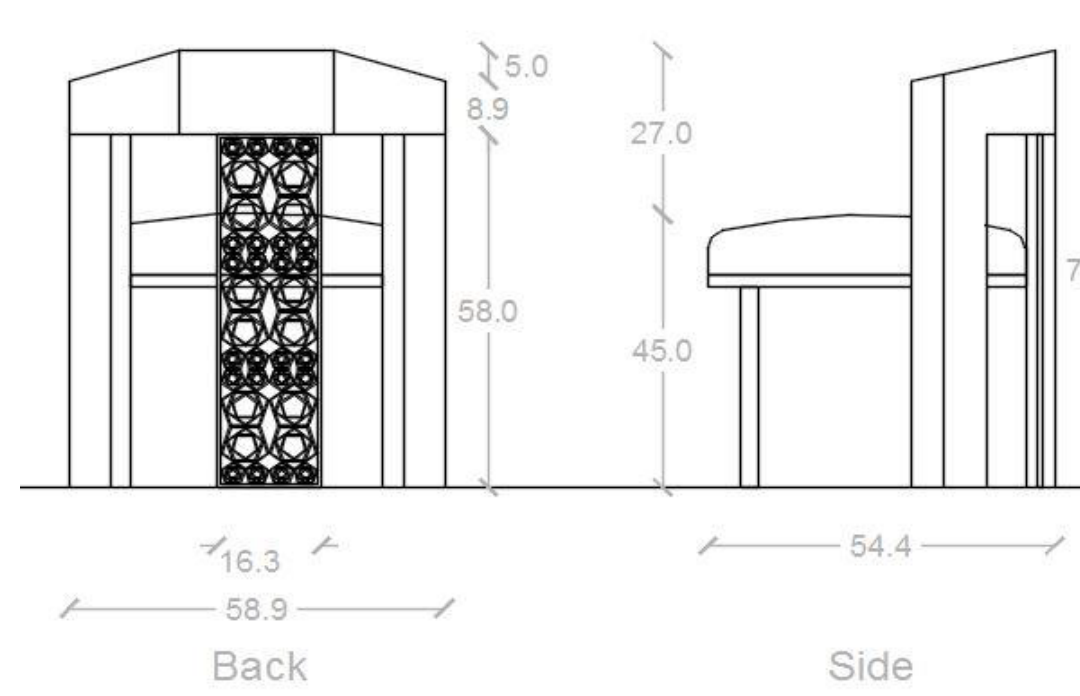

Steps of creating the fractal shape:

Step1: create the seed shape

Step2: Mirror the seed shape

Step3: Scale the seed shape by 0.8

Step 4: place the resulted shape from step 3 at both sides of the shape resulted from step 2

Step 5: scale the resulted shape from step 3 by 0.8

Step 6: place the resulted shape from step 5 at both sides of the shape resulted from step 4
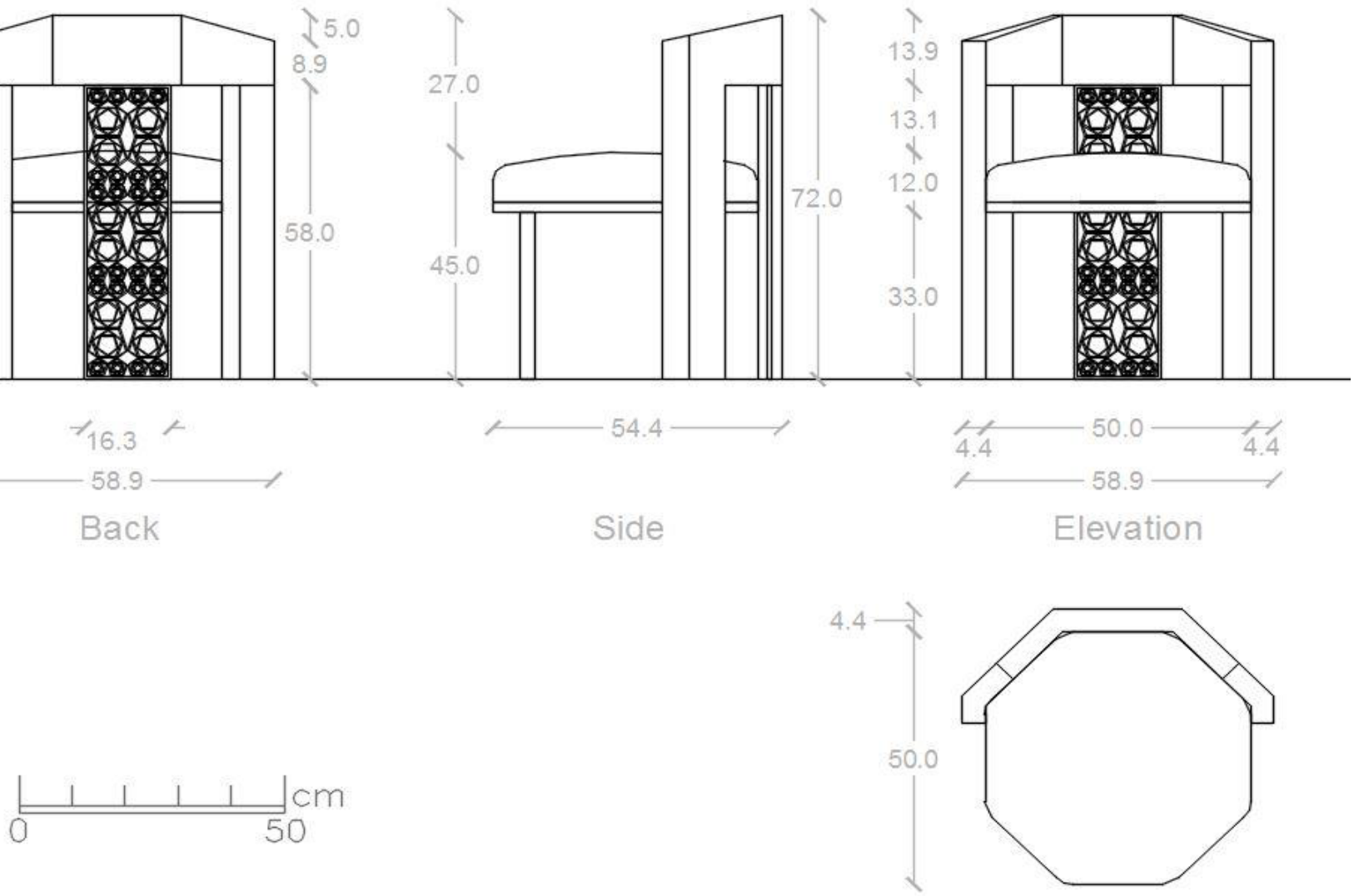

Figure 63: Using the created fractal shape in the design of dining table - by researcher

Here is also another cabinet designed using fractal geometrical shapes (Figure 66), that was inspired from the snake skin shapes as shown in Figure 64 and by applying the feedback and iteration process. As chorem in Fimure 65

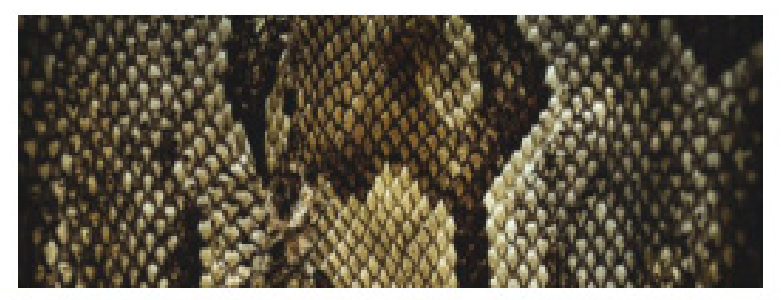

Figure 64: snake skin texture [46]
Step 7: scale the resulted shape from step 5 by 0.8 Step 8: place the resulted shape from step 5 at both sides of the shape resulted from step 7

The previous steps can be repeated till infinity Then by mirroring the result of step 8 and attaching it to copies of step 8 shape the final shape will be formed to be used in designing a side board.

And by using box counting dimension to determine the fractal dimension of the elevation of the side board design the fractal dimension $\mathrm{Db}=1.7$ as shown in Figure 67. 


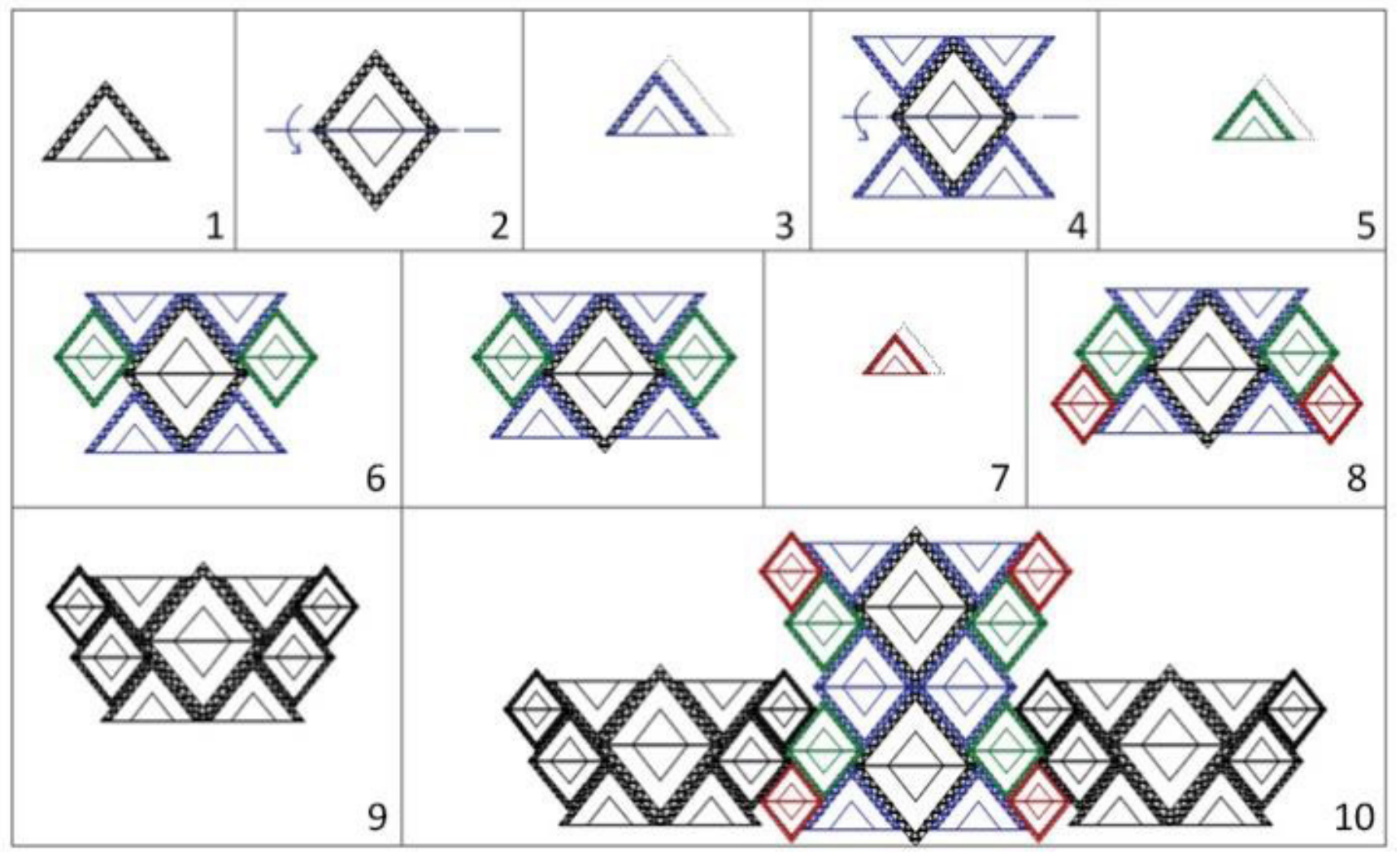

Figure 65: Creating fractal shapes using feedback and iteration system on the seed unit.

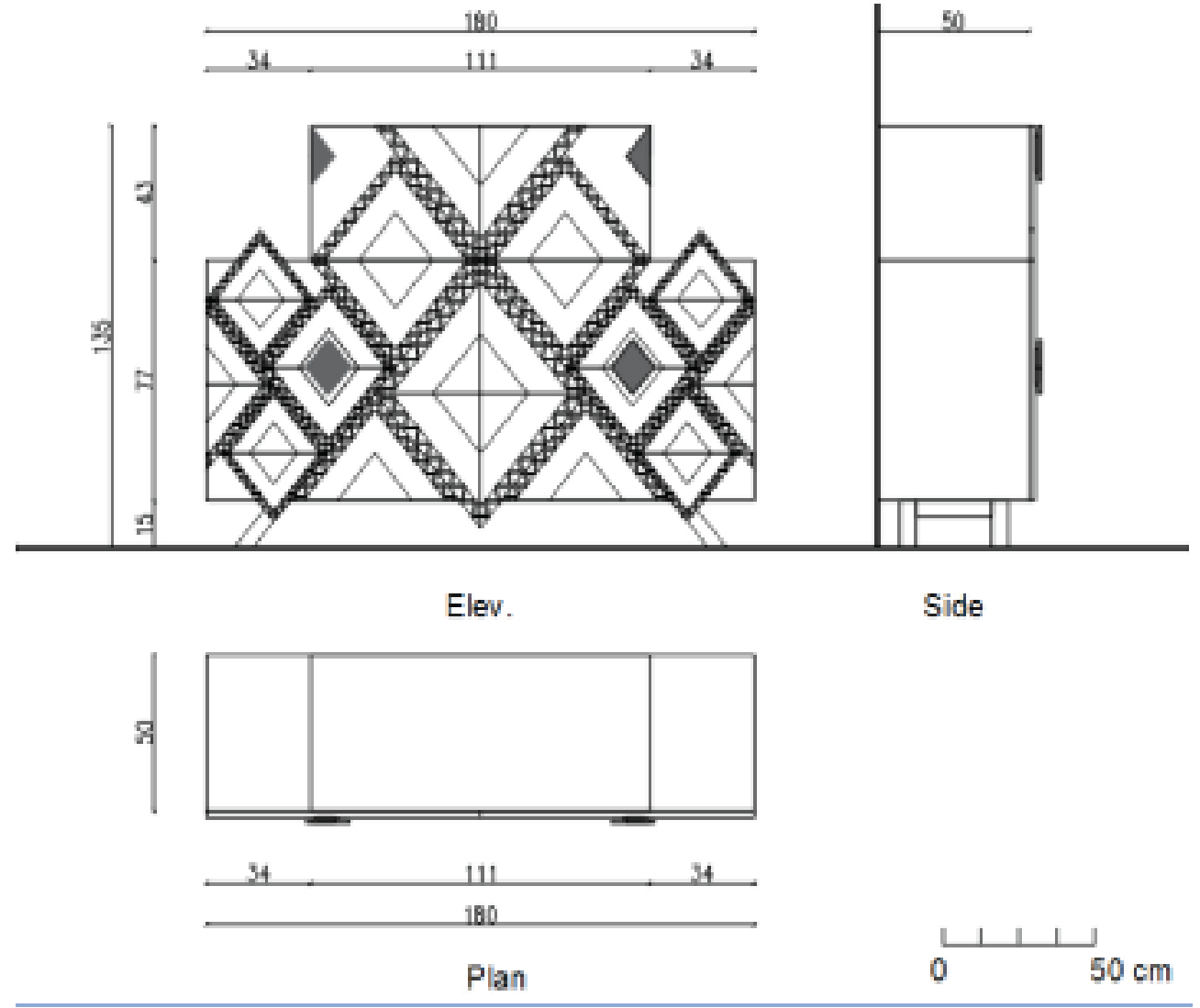

Figure 66: Fractal design for a side cabinet inspired from snake skin. - by resarcher 

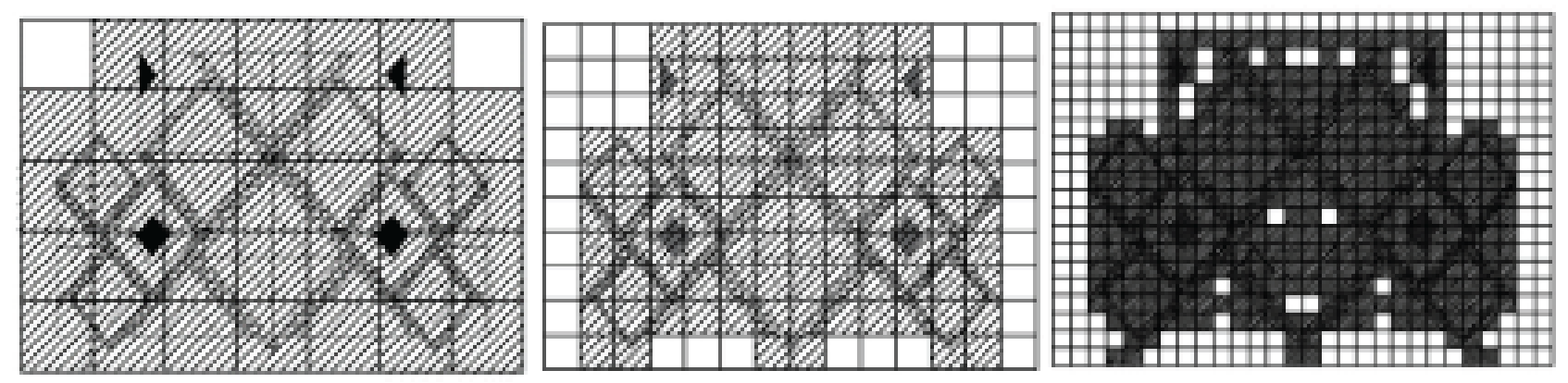

Figure 67: Box counting dimension for the side cabinet $\mathrm{Db}=1.7-$ by researcher

\section{Results:}

Research and analysis results are summarized in the following points:

1- The connection between fractal geometry, ecosystems and Interior design is deep and cannot be separated.

2- there are lots of common characteristics between fractal geometry, ecosystems, interior and architectural design such as self-similarity, scale, roughness and successive details, strong centers, boundaries, alternating repetition, positive space, good shape, local symmetries, nested quality and deep interlock, contrast, gradients, echoes, simplicity and inner calm.

5- Fractal geometry can offer new and innovative formations that can be used in interior and furniture designs.

3- Mathematical constructions such as Koch curve, Sierpinski triangle are true fractals in which they show a self-similar shapes through an infinite range of scale change, while natural objects, interior and architectural designs are fractal like as they show a limited growth in texture over a limited range of scale. 4- Fractal geometry's dimension cannot be measured using Euclidian rules; It can be measured using one of the three fractal dimensions [Self-similarity dimension (Ds), measured dimension (d), box counting dimension $(\mathrm{Db})]$

4- Connecting with nature is very important to the wellbeing of the humans, also using natural objects and materials helps humans to stay connected with nature for the wellbeing of their mental, emotional, physical health, and using fractal forms helps in that.

\section{References:}

\section{English References}

1- Ball, Philip: "Patterns in Nature", The University of Chicago Press, London, UK, 2016.

2-Ball, Philip: "Nature's Patterns: a tapestry in three parts. Flow", Oxford University Press, New York, USA, 2009.

3- Banerji, Anirban: "Fractal Symmetry of Protein Exterior", Springer Science \& Business Media, 2013. 4- Bovill, Carl:" Fractal Geometry: In Architecture and Design", Maple Press Company, USA, 1996.

5- Eglash, Ron:"African Fractals: Modern Computing and Indigenous Design", Rutgers University Press, London, UK, 2002.

6- Harris, James:"Fractal Architecture: Organic Design philosophy in theory and practice", University of New Mexico Press, USA, 2012.

7-Heinz-Otto Peitgen, Hartmut Jürgens, Dietmar Saupe :" Chaos and Fractals: New Frontiers of Science", Second Edition, Springer, USA, 2004.

8- Mandelbrot, Benoit B.: "The Fractal Geoetry of Nature", W. H. Freeman and Company, New York, 1983.

9- Michael Frame, Nathan Cohen: "Benoit Madlebrot: A Life in Many Dimensions", World Scientific Publishing Co., 2015.

10- Peitgen Jurgens, Maletsky Perciante:" Fractals for The Classroom: strategic activities volume one ", springer, 1991.

11- E. Lorenz, Wolfgang: "Fractals and fractal architecture", diploma thesis, faculty of architecture and spatial planning, Vienna University of technology, Austria, 2003.

12- Shafik, Nelly: "The Dual Language of Geometry in Gothic Architecture: The Symbolic Message of Euclidian Geometry versus the Visual Dialogue of Fractal Geometry", Peregrinations: Journal of Medieval Art \& Architecture, volume V, Number 2, 2015.

\section{Internet websites references}

13.http://islamic-arts.org/2012/cairos-islamic-architecture-7th-to-18th-centuries/

14.http://sinaitrekkingandsafari.com/main-attrac- 
tions/high-mountains/mt-sinai/

15.http://www.freshvista.com/2012/patterns-in-nature-contain-symmetry/

16.http://www.lindaschrank.com/borromini-series-essay

17.http://www.todocalidad.es/lugares-con-encanto/ barcelona-la-sagrada-familia/

18.http://fondosmovil.net/imagenes-de-arquitectura-siglo-20-para-pantalla-hd-2.html

19-https://ashley.camasirmakinesi.net/ancient-egypt-architecture-imhotep-first-egyptian-architect-2/

20.https://busy.org/@autonomysystem/fractals-or-natural-or-artificial-structures-or-geometric-patterns

21.https://users.math.yale.edu/public_html/People/ frame/Fractals/

22.https://ractalenlightenment.com/14556/fractals/ the-fractal-structure-of-hindu-temples/attachment/ virupaksha-temple-hampi

23.https://i.pinimg.com/originals/4a/ff/22/4aff22e20c6877ccf3d2226888c4101a.png

24. https://imgur.com/r/ImagesOfEgypt/NnwJjby

25.https://m.indiamart.com/proddetail/nesting-tables-21330332688.html

26.https://patterns.architexturez.net/doc/azcf-172604

27.https://people.math.ethz.ch/ fdalio/BachelorThesisLucaFontana.pdf

28.https://thoughtfuldesign.co/2019/01/27/gradient-furniture-collection/

29.https://www.allposters . com/-sp/Acacia-Tree-Serengeti-National-Park-Tanzania-East-Africa-Africa-Posters_i10811386_htm

30-https://www.almanac.com/news/weather-news/ weird-snow?utm_source=pinterest\&utm_medium=social

31.https://www.besthdwallpaper.com/mountains/ switzerland-snow-mountain-6k-dt_en-US-52607. html

32 - https://www.bigst ockphoto.com/i mage-79528771/stock-photo-notre-dame-in-parissouth-facade-with-rose-window

33 -https://ww w. flickr.com/photos/fabian-f/2517563561

34 . https: // ww w.instagram.com/maqam design/?hl=en

35.https://www.isis.stfc.ac.uk/Pages/Unravelling-the-boundaries-in-a-solidliquid-relationship. aspx 36-https://www.johnccatlin.com/blog/golden-phiphi-and-the-fibonacci-sequence

37- https://www.lachance.paris/borghesesofa

38.https://www.onlinepatiolawngardenstore.com/ why-spiders-are-attracted-to-your-home/

39-https://www.pellizzarimichele.it/blog/la-basilica-di-san-marco-venezia-i-pavimenti

40 . h t t p s : / / w w w.p in tere s t . c o m / $\operatorname{pin} / 354799276892446077 /$

41 . h t t p s : / / w w w. p i n t e r e s t.d k / pin/180003316339665796/

42.https://www.semanticscholar.org/paper/Fractals-and-Fractal-Design-in-Architecture-Belma/6223039dc7c52103616d4768ffac6e308d503265 43.https://www.stolenhistory.org/threads/mysteries-of-the-roman-pantheon.634/

44.https://www.tes.com/lessons/B5othymI9esFUw/ golden-rectangle-and-object-design

45 . h t t p s : / / w w w . p in tere s t . c o. k r / $\mathrm{pin} / 395683517243580963 /$

46.https://en.wikiarquitectura.com/building/ crypt-in-colonia-guell/\#cripta-guell-gaudi-barcelona-wikiarquitectura-17 